\title{
PEMANFAATAN THERMOELECTRIC ENERGY GENERATOR (TEG) SEBAGAI SUMBER ENERGI LISTRIK MENGGUNAKAN BUCK CONVERTER DENGAN UMPAN BALIK TEGANGAN BERBASIS IC TL494
}

\author{
Masaji ${ }^{*}$, Mochammad Facta dan Bambang Winardi \\ Departemen Teknik Elektro, Universitas Diponegoro \\ Jl. Prof. Sudharto, SH, Kampus UNDIP Tembalang, Semarang 50275, Indonesia \\ ${ }^{*}$ E-mail: masajie_22@yahoo.com
}

\begin{abstract}
Abstrak
Pemanfaatan energi baru dan terbarukan yang ramah lingkngan terus dikembangkan, selain potensi dari energi surya, air, dan angin terdapat sumber energi lain yaitu panas. Tanpa disadari energi panas terbuang percuma dalam kehidupan sehari-hari, contohnya pada saluran gas buang kendaraan dan cerobong asap pada industri. Energi panas yang terbuang dapat diubah menjadi energi listrik menggunakan thermoelectric energy generator (TEG). Modul termo elektrik bekerja sesuai efek seeback. Tegangan termoelektrik dipengaruhi oleh koefisien seeback dan perbedaan suhu. Oleh karena itu tegangan yang dihasilkan tidak stabil. Untuk itu pada penelitian ini dirancang pembangkit listrik dengan menggunakan modul termoelektrik kemudian energi yang dihasilkan dimanfaatkan untuk menyuplai beban menggunakan konverter arus searah tipe buck converter dengan umpan balik tegangan berbasis IC TL494 sebagai rangkaian pembangkit sinyal PWM. Umpan balik tegangan berfungsi untuk memonitor tegangan keluaran buck converter, yang akan diumpankan pada komparator yang ada di dalam IC TL494. Hasil pengujian yang sudah dilakukan didapatkan bahwa tegangan keluaran buck converter dengan umpan balik tegangan cenderung konstan dengan adanya perubahan nilai resistif pada sisi beban. Tegangan keluaran rata - rata buck converter dengan umpan balik tegangan sebesar 5 volt. Efisiensi buck converter dengan umpan balik tegangan rata - rata diatas $60 \%$.
\end{abstract}

Kata kunci: termoelektrik, konverter arus searah, buck converter, umpan balik, IC TL494

\begin{abstract}
Utilization of new and renewable energy that is environmentally friendly continues to be developed, in addition to the potential of solar, water, and wind energy there are other energy sources namely heat. Unwittingly, heat energy is wasted in everyday life, for example on vehicle exhaust gases and chimneys in the industry. Wasted heat energy can be converted into electrical energy using a thermoelectric energy generator (TEG). The electric thermo module works according to the seeback effect. The thermoelectric voltage is affected by the seeback coefficient and temperature difference. Therefore the resulting voltage is unstable. For this reason, this project designed a power plant using a thermoelectric module and the energy produced was used to supply the load using a buck converter with voltage feedback based on IC TL494 as a PWM signal generator circuit. Voltage feedback serves to monitor buck converter output voltage, which will be fed to the comparator in IC TL494. The test results that have been made have been found that the buck converter output voltage with voltage feedback tends to be constant with a change in the resistive value on the load side. The average output of buck converter with feedback is 5 volt. The efficiency buck converter above $60 \%$.
\end{abstract}

Keywords: thermoelectric, direct current converter, buck converter, feedback, IC TL494

\section{Pendahuluan}

Kebutuhan energi terus meningkat seiring dengan berkembangnya zaman. Salah satu energi yang paling penting adalah energi listrik. Di Indonesia energi listrik memiliki peran vital dalam kehidupan sehari-hari [1]. Konsumsi energi listrik terus meningkat setiap tahun [2]. Saat ini pembangkitan energi listrik masih didominasi pada energi fosil seperti minyak bumi, batu bara, dan gas alam [3]. Sebagai energi yang tidak dapat diperbarui jumlah energi fosil semakin berkurang setiap tahun. Penggunaan bahan bakar fosil juga memiliki dampak pencemaran lingkungan. Oleh karena itu diperlukan pengembangan sumber energi baru dan terbarukan (EBT) yang ramah terhadap lingkungan.

Pengembangan energi baru dan terbarukan masih berfokus pada energi surya, air, dan angin. Selain 3 
sumber tersebut terdapat sumber energi lain yang dapat dimanfaatkan yaitu panas atau kalor. Tanpa disadari banyak energi panas terbuang seperti pada exhaust atau saluran gas buang pada mesin kendaraan bermotor dan cerobong asap industri. Energi panas yang terbuang dapat dirubah menjadi listrik menggunakan modul thermoelectric energy generator (TEG) [4].

Termoelektrik merubah energi panas menjadi listrik menggunakan efek seeback [5]. Termoelektrik memiliki beberapa kelebihan dibanding pembangkit listrik lainnya, antara lain tidak bersuara karena tidak ada komponen yang bergerak, ramah lingkungan, dapat digunakan dalam skala kecil maupun besar, dan memiliki tingkat keandalan yang tinggi [6]. Kemampuan termoelektrik dipengaruhi oleh koefisien seeback dan suhu [7], oleh karena itu daya yang dihasilkan termoelektrik tidak stabil.

Pada penelitian terdahulu [8] penggunaan modul TEC12706 memiliki tegangan output tertinggi sebesar $0,55 \mathrm{~V}$ serta efisiensi yang rendah. Kemudian pada penelitian [9] tegangan keluaran yang dihasilkan termoelektrik langsung dihubungkan ke beban sehingga tegangan keluaran berubah-ubah.

Berdasarkan penelitian terdahulu maka pada penelitian ini dirancang sistem pembangkitan listrik menggunakan termoelektrik yang diharapkan menghasilkan tegangan 10-12V kemudian listrik yang dihasilkan diturunkan menggunakan konverter arus searah buck menjadi $5 \mathrm{~V}$ dengan umpan balik tegangan sehingga diharapkan tegangan keluaran tetap stabil meskipun terjadi perubahan tegangan masukan dan perubahan beban.

\section{Metode}

Perancangan pada penelitian ini terdiri dari rangkaian sumber tegangan, rangkaian konverter arus searah tipe buck converter, rangkaian kontrol pembangkit sinyal PWM, dan beban.
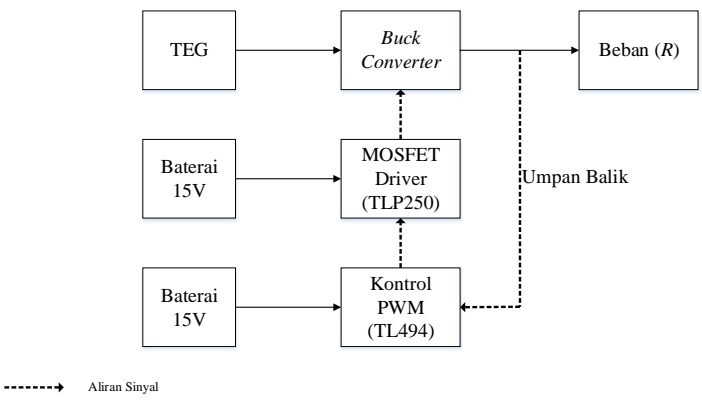

Gambar 1. Blok Diagram Alat

\subsection{Konverter Arus Searah Tipe Buck Converter}

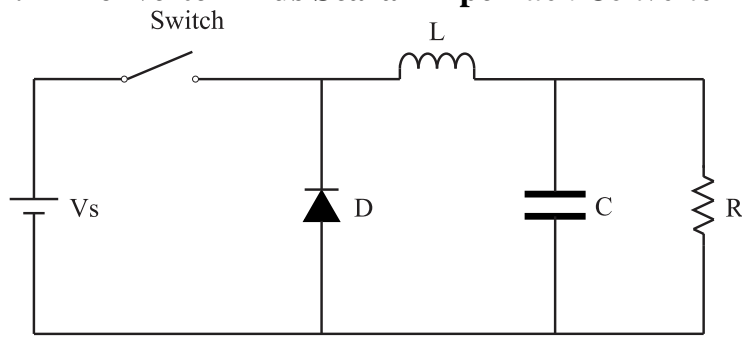

Gambar 2. Rangkaian Buck Converter

Konverter arus searah tipe Buck Converter digunakan sebagai penyedia daya DC untuk suplai beban resistor keramik pada penelitian penelitianini. Komponen komponen penyusun yang digunakan pada konverter arus searah tipe Buck Converter antara lain :

\section{Sumber Tegangan Arus Searah}

Sumber yang dipakai untuk menyuplai rangkaian konverter arus searah didapat dari pembangkitan listrik menggunakan termoelektrik. Tegangan yang dihasilkan sebesar $10-12 \mathrm{~V}$.

\section{Saklar}

Komponen pensaklaran yang digunakan pada konverter arus searah pada penelitianini adalah MOSFET. Pemilihan MOSFET harus mempertimbangkan nilai tegangan dan arus operasi. Tegangan masukan Konverter arus searah adalah $10-12 \mathrm{~V}$ volt.

MOSFET yang dipakai adalah MOSFET IRFZ44N yang mempunyai tegangan Breakdown Drain-Source $\mathrm{V}_{(\mathrm{BR}) \mathrm{DS}}$ adalah 55 volt dan kemampuan arus drain maksimal 49 ampere [15], sehingga pemakaian MOSFET tipe IRFZ44N ini aman untuk dipakai karena arus maksimum yang dialirkan rangkaian daya yaitu $1 \mathrm{~A}$.

\section{Dioda}

Dioda yang digunakan adalah MUR1560. Dioda ini dipilih karena mempunyai sifat ultrafast recovery dengan waktu pemulihan $60 \mathrm{~ns}$ [16].

\section{Induktor}

Induktor yang digunakan pada konverter arus searah ini diperhitungkan nilainya untuk disesuaikan dengan parameter lain yang berhubungan. Induktor yang digunakan merupakan induktor jenis solenoida yang dibuat dari kawat tembaga yang dililitkan pada inti ferit.

$$
\begin{aligned}
L_{\text {min }} & =\frac{(1-D) R}{2 f} \\
& =\frac{(1-0,5) 100}{2.20000}=1,25 \mathrm{mH}
\end{aligned}
$$


Induktor yang digunakan sebesar $1,5 \mathrm{mH}$. Pemilihan nilai induktor lebih besar dari nilai induktor minimal ( $\mathrm{L}$ > $\mathrm{L}_{\min }$ ) agar Buck Converter bekerja pada Continous Current Mode (CCM) [3].

\section{Kapasitor}

Kapasitor berfungsi sebagai filter tegangan untuk membatasi ripple tegangan yang disebabkan kenaikan nilai beban. Kapasitor yang digunakan untuk perancangan buck converter ini mempunyai nilai $470 \mu \mathrm{F}$. Hal ini dilakukan untuk mendapatkan tegangan ripple puncak ke puncak kapasitor $\left(\Delta V_{0}\right)$ yang kecil.

$$
\begin{aligned}
C & =\frac{(1-D)}{8 L \frac{\Delta V o}{V_{O}} f^{2}} \\
& =\frac{(1-0,5)}{8 \cdot 1,5 \times 10^{-3} \cdot \frac{0,005}{5} \cdot 20000^{2}} \\
& =10,416 \mu F
\end{aligned}
$$

Pada perhitungan kapasitor didapat nilai kapasitansi kapasitor sebesar $10,416 \mu \mathrm{F}$. Pada realisasinya kapasitor yang dipasang adalah $470 \mu \mathrm{F}$. Pemilihan nilai kapasitansi kapasitor yang lebih besar daripada nilai perhitungan bertujuan untuk mengurangi ripple tegangan keluaran.

\subsection{Rangkaian Kontrol Pembangkit Sinyal PWM dengan Umpan Balik Tegangan}

PWM atau disebut Pulse Width Modulation digunakan untuk pengontrolan MOSFET. MOSFET dipicu untuk menjadi saklar dengan frekuensi tinggi. Proses pensaklaran atau switching ini diaplikasikan dengan T-on (waktu saat switch tertutup) dan $\mathrm{T}$ (waktu satu periode pulsa) atau biasa disebut Duty Cycle. Pada penelitianini sinyal PWM yang dihasikan dari IC TL494 dan rangkaian MOSFET driver. Pada IC TL494 terdapat pin feedback yang berfungsi menerima sinyal umpan balik dari tegangan keluaran sistem

Nilai frekuensi osilasi pada rangkaian kontrol IC TL494 diatur oleh dua komponen yang dihubungkan dengan kaki 5 dan 6. Kaki 5 IC TL494 adalah Resistor Timer (RT) dan kaki 6 IC TL494 adalah Capacitor Timer (CT) [4].

$$
\begin{aligned}
\mathrm{f}_{\mathrm{S}} & =\frac{1}{\mathrm{R}_{\mathrm{T} .} \cdot \mathrm{C}_{\mathrm{T}}} \\
\mathrm{f}_{\text {osc(max) }} & =\frac{1}{20000 \cdot 1 \cdot 10^{-9}} \\
& =50 \mathrm{kHz}\left(\mathrm{R}_{\mathrm{Var}}=0 \Omega\right) \\
\mathrm{f}_{\text {osc(min) }} & =\frac{1}{70000.1 \cdot 10^{-9}} \\
& =14,285 \mathrm{kHz}\left(\mathrm{R}_{\mathrm{Var}}=50 \mathrm{k} \Omega\right)
\end{aligned}
$$

Perancangan umpan balik yang digunakan pada penelitian ini adalah umpan balik teganan. Umpan balik tegangan berfungsi untuk memonitor tegangan keluaran buck converter. Pada perancangan umpan balik tegangan terdapat potensio $100 \mathrm{k} \Omega$ yang berfungsi sebagai sensor tegangan keluaran buck converter.

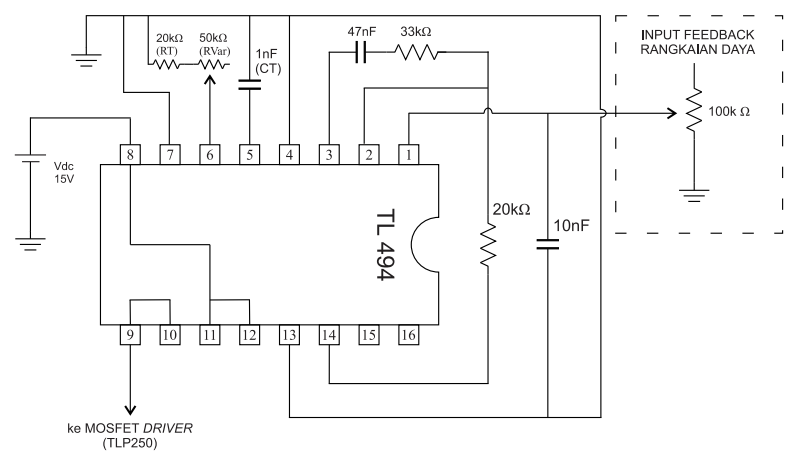

Gambar 3. Rangkaian IC TL494 dengan umpan balik tegangan

\subsection{Perancangan Catu Daya Arus Searah (DC) \\ 2.3.1. Perancamgam Thermoelectric Energy Generator}

TEG yang digunakan sebagai catu daya rangkaian konverter arus searah buck adalah tipe TEC1-12706 dengan jumlah 6 sel yang disusun secara seri dengan bagian panas diletakkan diatas setrika sebagai sumber panas, kemudian bagian dingin diletakkan pada waterblock sebagai sumber dingin. Dengan susunan seperti ini diharapkan TEG dapat menghasilkan tegangan DC $10-12 \mathrm{~V}$.

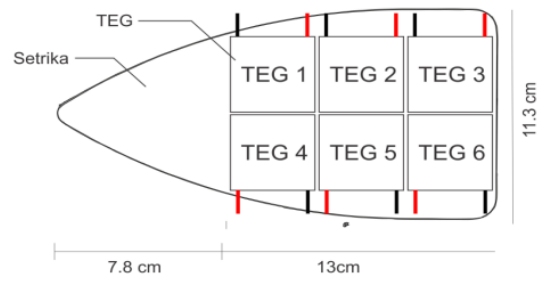

Gambar 4. Susunan penampang TEG tampak atas

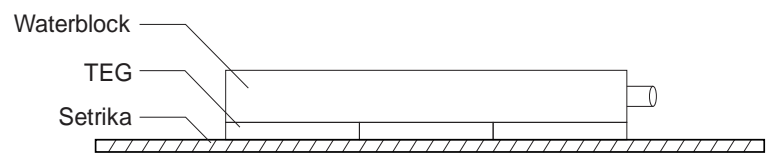

Gambar 5. Susunan penampang TEG tampak samping

\subsubsection{Perancamgam Catu Daya DC Rangkaian Kontrol}

Pada penelitianini digunakan tegangan Vin sebesar $15 \mathrm{~V}$ untuk rangkaian kontrol ICTL494 dan rangkaian driver TLP250. Vin $15 \mathrm{~V}$ didapat dari baterai $6 \mathrm{~V}$ yang kemudian dinaikkan tegangannya menggunakan boost converter menjadi $15 \mathrm{~V}$. 


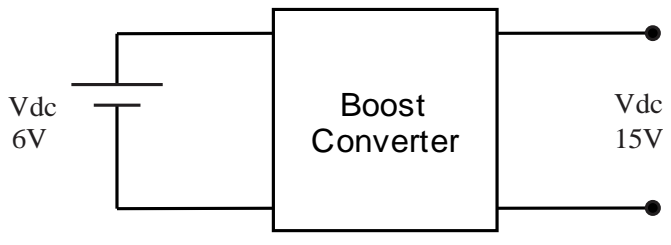

Gambar 6. Rangkaian supply kontrol PWM

\subsection{Beban}

Beban yang digunakan pada Penelitianini adalah resistor keramik dengan 6 variasi tahanan berbeda. Resistor beban terdiri dari $15 \Omega, 30 \Omega, 50 \Omega, 75 \Omega, 100 \Omega$ dan $220 \Omega$. Penggunaan resistor berbeda untuk melihat respon perubahan beban terhadap tegangan keluaran buck converter.

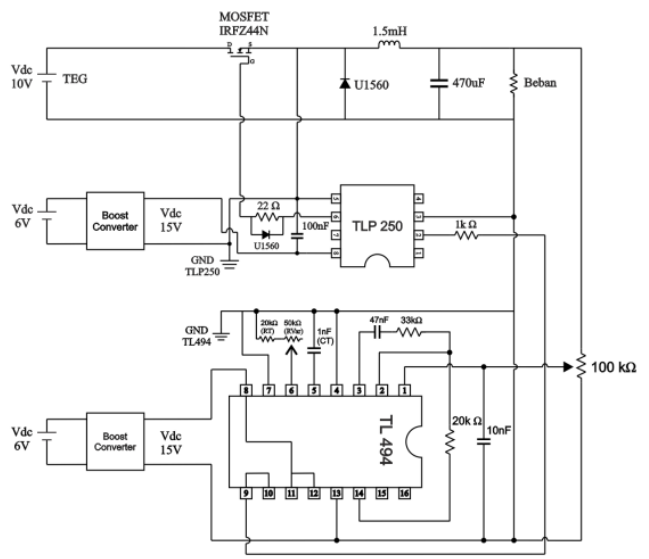

Gambar 7. Skema rangkaian keseluruhan

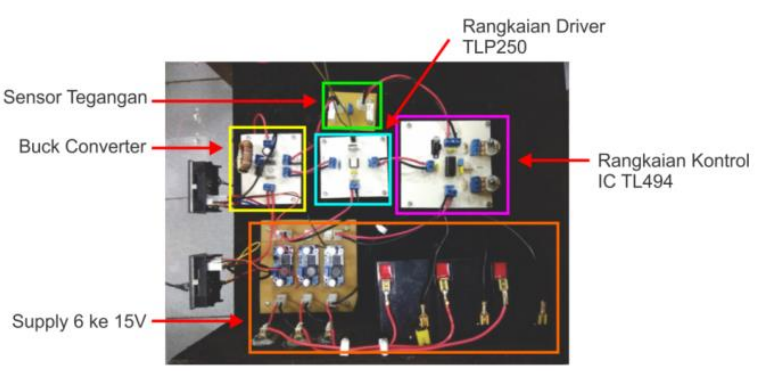

Gambar 8. Realisasi rangkaian keseluruhan

\section{Hasil dan Analisis \\ 3.1 Pengujian Rangkaian Kontrol Sinyal PWM dengan Umpan Balik Tegangan}

Rangkaian kontrol pembangkit sinyal PWM yang digunakan pada Penelitianini adalah IC TL494 dengan satu keluaran (single-ended). Pengujian rangkaian kontrol pembangkit sinyal PWM dilakukan dalam kondisi beban telah terpasang dan sinyal feedback juga terpasang ke rangkaian kontrol. Pengujian dilakukan dengan melihat respon gelombang kontrol ketika beban berubah.

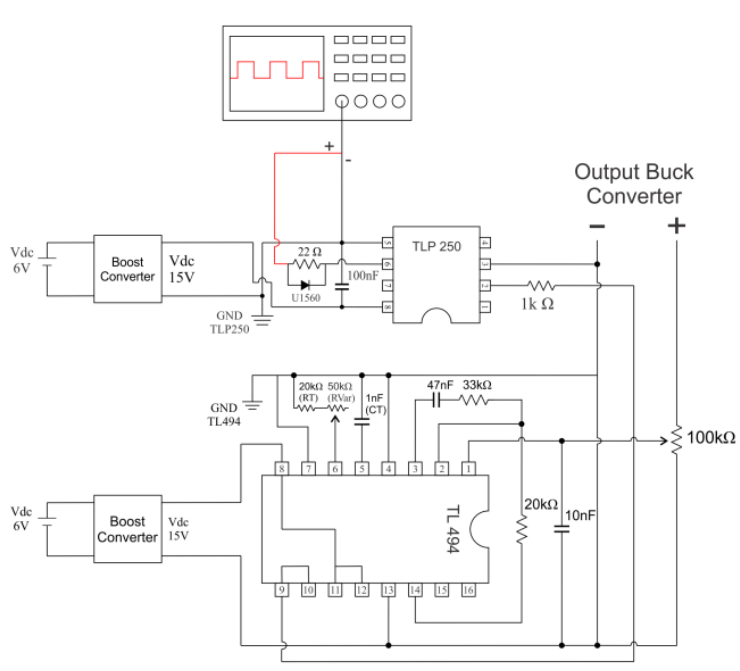

Gambar 9. Pengujian rangkaian kontrol pembangkit sinyal PWM dengan IC TL494

Gambar 9 adalah pengujian rangkaian kontrol pembangkit sinyal PWM berbasis IC TL494 dengan umpan balik dari keluaran buck converter. Pengujian dilakukan pada keluaran TLP250 sebagai driver rangkaian kontrol pembangkit sinyal PWM IC TL494. Sinyal PWM digunakan untuk memicu MOSFET pada rangkaian buck converter.

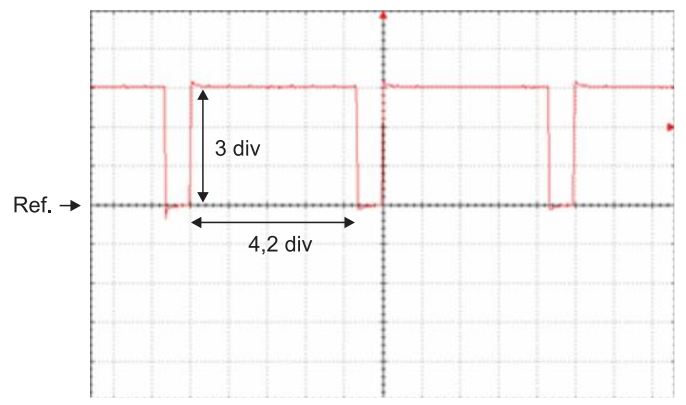

Gambar 10. Gelombang keluaran sinyal PWM TL494 dengan driver TLP250 ketika duty cycle $86,7 \%$

Gambar 10 merupakan gelombang keluaran dari IC TL494 ketika duty cycle $86,7 \%$ dan kondisi buck converter belum menyala (off). Pada Gambar 10 terlihat bahwa gelombang kontrol dari IC TL494 dengan feedback ketika kondisi buck converter off mengakibatkan tegangan pada pin 1 yang terhubung dengan output buck converter bernilai 0 Volt (tidak bertegangan). Pin 2 pada IC TL494 telah terhubung dengan tegangan referensi, sehingga komparator pada IC TL494 membandingkan tegangan pin 1 noninverting dengan pin 2 inverting. Tegangan pada pin 1 noninverting lebih kecil daripada tegangan pada pin 2 inverting, sehingga akan menaikkan duty cycle. Dalam penelitian ini frekuensi pensaklaran atau switching diatur sebesar 20,08 $\mathrm{kHz}$. 


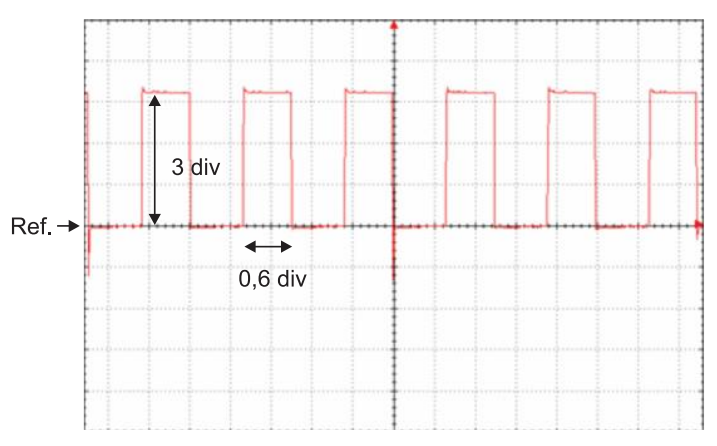

Gambar 11. Gelombang keluaran sinyal PWM TL494 dengan driver TLP250 ketika duty cycle 46,8\%

Gambar 11 menampilkan hasil gelombang keluaran sinyal PWM ketika duty cycle 46,8 \% dan kondisi buck converter telah menyala (on) dengan beban sebesar 100 $\Omega$. Ketika buck converter telah menyala (on) dengan beban terpasang $100 \Omega$ maka tegangan keluaran buck converter dengan feedback sebesar 5,01 Volt. Pada kondisi ini rangkaian kontrol memberikan respon dengan mengeluarkan duty cycle sebesar 46,8 \%. Kondisi duty cycle yang semula bernilai $86,7 \%$ pada Gambar 10 ketika buck converter off, duty cycle secara otomatis berubah menjadi 46,8\% ketika buck converter on. Hal ini karena tegangan keluaran buck converter diumpan balik ke pin 1 IC TL494, sehingga pada pin 1 noninverting TL494 yang semula tidak bertegangan mendapat tegangan dari umpan balik tegangan buck converter. Frekuensi pensaklaran atau switching diatur sebesar 20,08 kHz.

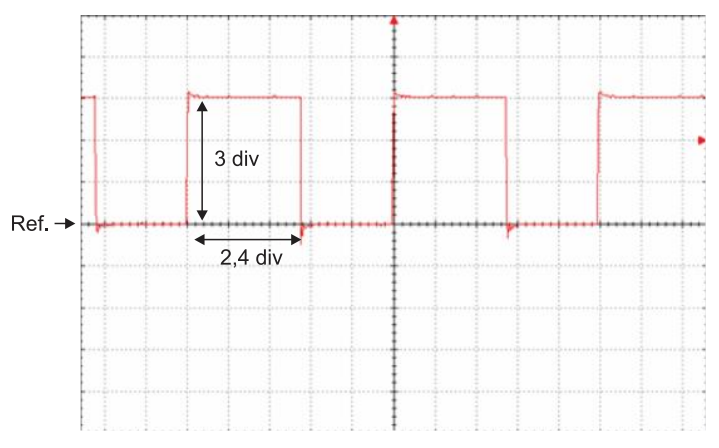

Gambar 12. Gelombang keluaran sinyal PWM TL494 dengan driver TLP250 ketika duty cycle 55,4\%

Gambar 12 adalah hasil gelombang keluaran sinyal PWM ketika duty cycle $55,4 \%$ dan beban buck converter sebesar 15,32 $\Omega$. Ketika beban terpasang 15,32 $\Omega$ maka untuk mempertahankan tegangan sebesar 5 Volt, rangkaian kontrol memberikan respon dengan mengeluarkan duty cycle sebesar 55,4 \%. Tegangan keluaran buck converter tetap stabil walau terjadi perubahan beban dan duty cycle. Hal ini karena tegangan keluaran buck converter diumpan balik ke rangkaian kontrol. Hubungan duty cycle pada buck converter dengan umpan balik tegangan berbanding terbalik terhadap beban. Semakin kecil nilai tahanan beban pada buck converter, maka semakin besar duty cycle yang dihasilkan. Frekuensi switching yang terbaca pada kondisi beban $15,32 \Omega$ adalah $20,08 \mathrm{kHz}$.

\subsection{Pengujian Tegangan Keluaran Rangkaian Buck Converter dengan Umpan Balik Tegangan}

Pengujian tegangan keluaran buck converter dengan umpan balik dapat dilihat pada Gambar 13. Gambar 13 menunjukkan bahwa keluaran dari buck converter diumpan balik ke rangkaian kontrol sinyal PWM, sehingga rangkaian buck converter pada Gambar 13 dalam kondisi close loop.

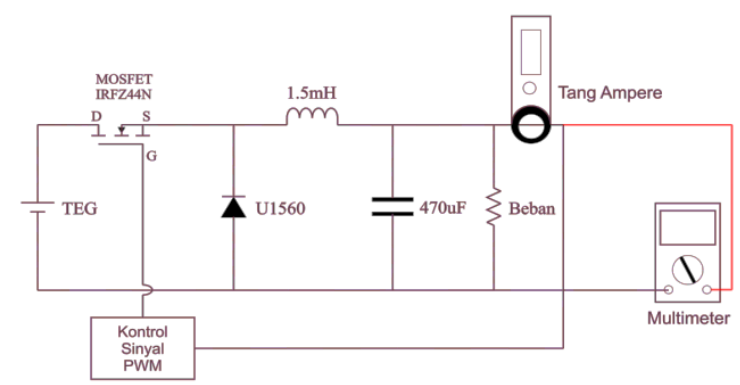

Gambar 13. Pengujian tegangan keluaran buck converter dengan umpan balik

Tabel 1. Hasil pengujian tegangan keluaran buck converter dengan umpan balik tegangan

\begin{tabular}{lllllll}
\hline No & $\begin{array}{l}\text { Vin } \\
(\mathrm{V})\end{array}$ & $\begin{array}{l}\text { lin } \\
(\mathrm{A})\end{array}$ & $\begin{array}{l}\text { Vout } \\
(\mathrm{V})\end{array}$ & $\begin{array}{l}\text { Iout } \\
(\mathrm{A})\end{array}$ & $\begin{array}{l}\text { Beban } \\
(\Omega)\end{array}$ & $\begin{array}{l}\text { Duty } \\
\text { Cycle } \\
(\%)\end{array}$ \\
\hline 1 & 6,02 & 0,290 & 4,28 & 0,270 & 15 & 86,7 \\
2 & 9,3 & 0,137 & 5,009 & 0,160 & 30 & 66,5 \\
3 & 10,72 & 0,069 & 5,013 & 0,093 & 50 & 55,6 \\
4 & 10,89 & 0,048 & 5,014 & 0,066 & 75 & 53 \\
5 & 11,13 & 0,037 & 5,015 & 0,049 & 100 & 45,3 \\
6 & 10,17 & 0,02 & 5,001 & 0,022 & 220 & 34,4 \\
\hline
\end{tabular}

Pada Tabel 4.1 terlihat bahwa ada perubahan duty cycle terhadap beban. Data diatas menunjukkan bahwa semakin kecil beban pada buck converter maka semakin besar duty cycle yang dihasilkan Dapat disimpulkan hubungan antara duty cycle dengan beban adalah berbanding terbalik.. Frekuensi switching diatur pada 20,08 kHz.

Buck converter dengan feedback tegangan menghasilkan tegangan keluaran yang konstan $5 \mathrm{~V}$ karena fungsi feedback sebagai pengoreksi selisih antara tegangan keluaran dan referensi. Selisih dari tegangan tersebut diumpan balik ke rangkaian kontrol sebagai masukan, sehingga tegangan keluaran dari buck converter berusaha stabil walau beban diubah-ubah. Pada beban $15 \Omega$ terjadi penurunan Vout sebesar 4,28V. Hal ini disebabkan daya dari TEG tidak mampu menyuplai beban $15 \Omega$ 


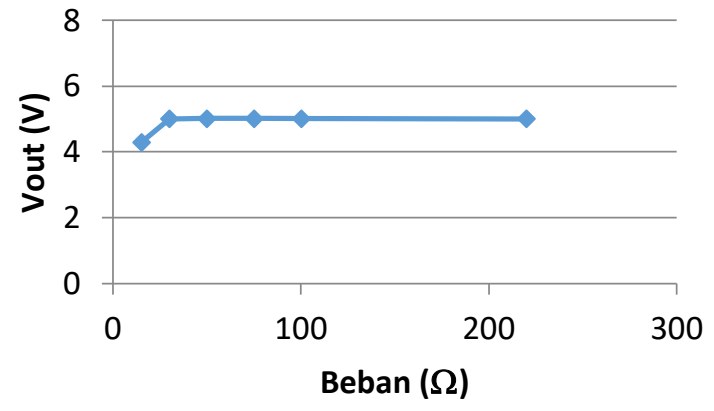

Gambar 14. Grafik tegangan keluaran buck converter dengan feedback tegangan

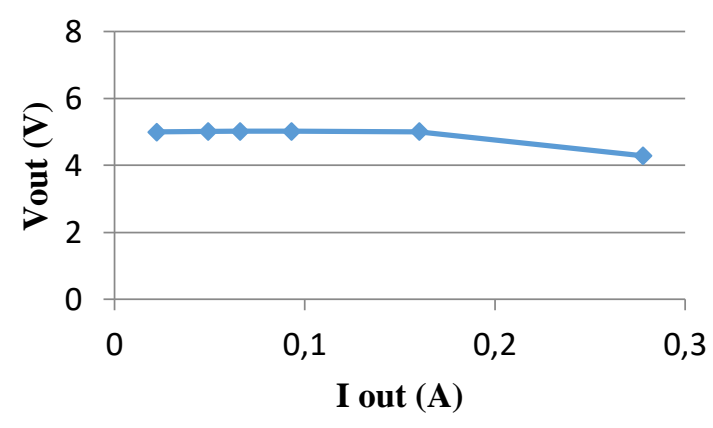

Gambar 15. Grafik tegangan keluaran buck converter dengan feedback arus keluaran

Dapat dilihat bahwa tegangan keluaran cenderung konstan pada $5 \mathrm{~V}$ sedangkan arus berubah sesuai dengan perubahan beban. Dengan tegangan yang sama semakin besar beban maka arus keluaran akan semakin kecil, sebaliknya jika beban semakin kecil maka arus beban akan semakin besar.

\subsection{Perhitungan Efisiensi Buck Converter}

Efisiensi buck converter dapat dicari dengan menghitung daya input $\left(\mathrm{P}_{\mathrm{in}}\right)$ dan daya output $\left(\mathrm{P}_{\text {out }}\right)$ pada buck converter dengan variasi beban anatara $15 \Omega$ hingga 100 $\Omega$, dengan menggunakan Persamaan 4 berikut.

$\eta=\frac{P_{\text {OUT }}}{P_{I N}} \times 100 \%$

dengan :

$$
\begin{aligned}
& P_{\text {in }}=V_{\text {in }} \times I_{\text {in }} \\
& P_{\text {out }}=V_{\text {out }} \times I_{\text {out }}
\end{aligned}
$$

Nilai efisiensi dari buck converter dengan feedback tegangan memiliki efisiensi tertinggi sebesar $67,9 \%$ pada beban $15 \Omega$ dan efisiensi terendah pada beban $220 \Omega$ dengan efisiensi sebesar $54 \%$. Rata-rata efisiensi dari buck converter dengan feedback tegangan sebesar $61,9 \%$. Nilai efisiensi dari buck converter dengan feedback tegangan memiliki efisiensi dengan nilai rata-rata efisiensi tiap variasi beban diatas $60 \%$.
Tabel 2. Hasil perhitungan efisiensi buck converter dengan umpan balik tegangan

\begin{tabular}{llllllll}
\hline $\begin{array}{l}\text { Vin } \\
(\mathrm{V})\end{array}$ & $\begin{array}{l}\text { Iin } \\
(\mathrm{A})\end{array}$ & $\begin{array}{l}\text { Pin } \\
(\mathrm{W})\end{array}$ & $\begin{array}{l}\text { Vout } \\
(\mathrm{V})\end{array}$ & $\begin{array}{l}\text { Iout } \\
(\mathrm{A})\end{array}$ & $\begin{array}{l}\text { Pout } \\
(\mathrm{W})\end{array}$ & $\begin{array}{l}\eta \\
(\%)\end{array}$ & $\begin{array}{l}\mathrm{R} \\
(\Omega)\end{array}$ \\
\hline 6,02 & 0,290 & 1,75 & 4,28 & 0,270 & 1,19 & 67,9 & 15 \\
9,3 & 0,137 & 1,27 & 5,00 & 0,160 & 0,80 & 63,1 & 30 \\
10,72 & 0,069 & 0,74 & 5,01 & 0,093 & 0,46 & 63,0 & 50 \\
10,89 & 0,048 & 0,52 & 5,01 & 0,066 & 0,33 & 62,9 & 75 \\
11,13 & 0,037 & 0,41 & 5,01 & 0,049 & 0,24 & 60,3 & 100 \\
10,17 & 0,02 & 0,20 & 5,00 & 0,022 & 0,11 & 54,0 & 220 \\
\hline
\end{tabular}

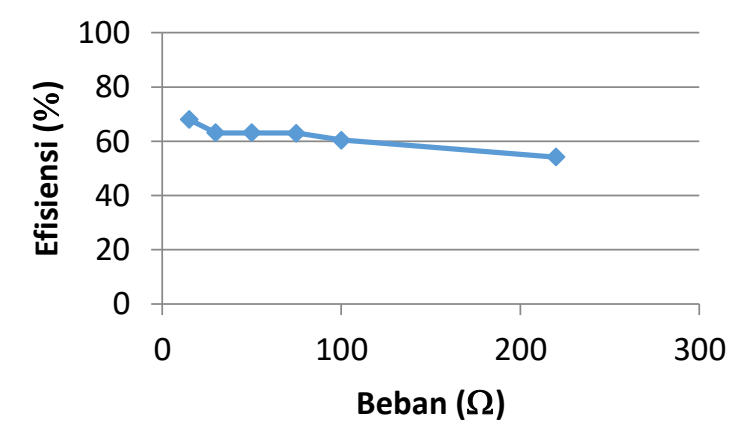

Gambar 16. Grafik hubungan efisiensi buck converter dengan feedback tegangan terhadap beban

Pada Gambar 16 menunjukkan grafik hubungan antara efisiensi buck converter dengan feedback tegangan terhadap beban. Ketika beban berubah dari $15 \Omega$ hingga $220 \Omega$ maka efisiensi akan mengalami penurunan. Semakin besar nilai beban semakin kecil nilai efisiensi buck converter dengan feedback tegangan

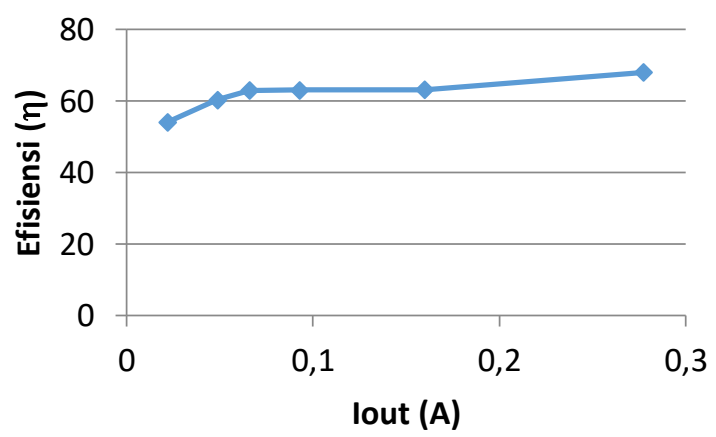

Gambar 17. Grafik hubungan efisiensi buck converter dengan feedback tegangan terhadap arus beban

Gambar 17 menunjukkan perbandingan efisiensi buck converter dengan arus keluaran. Dapat dilihat bahwa efisiensi berbanding lurus dengan arus keluaran semakin besar arus keluaran maka efisiensi pada buck converter akan semakin tinggi. Sebaliknya jika arus keluaran semakin kecil maka efisiensi pada buck converter akan semakin rendah. Hal ini sesuai dengan persamaan 4 yang menunjukkan bahwa efisiensi berbanding lurus dengan arus keluaran. 


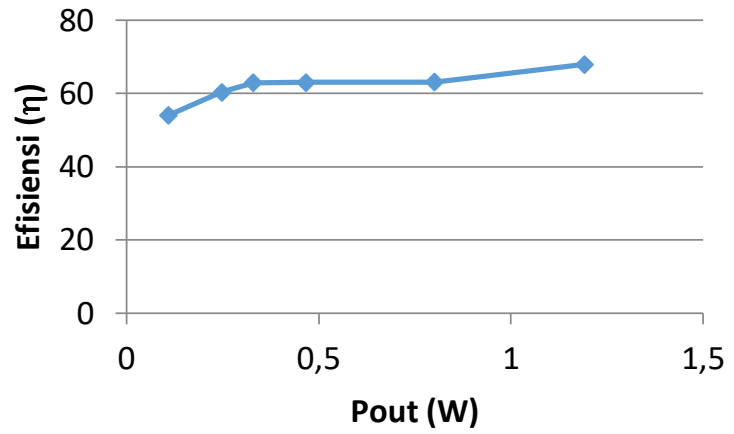

Gambar 18. Grafik hubungan efisiensi buck converter dengan feedback tegangan terhadap daya beban

Gambar 18 menunjukkan perbandingan efisiensi buck converter dengan daya keluaran. Terlihat bahwa hubungan efisiensi berbanding lurus dengan daya keluaran. Semakin besar daya keluaran maka efisiensi akan semakin tinggi. Sebaliknya jika daya keluaran buck converter semakin kecil maka efisiensi akan semakin rendah. Hal ini sudah sesuai dengan Persamaan 4 yang menunjukkan bahwa efisiensi berbanding lurus dengan daya keluaran $\left(\mathrm{P}_{\text {out }}\right)$.

\section{Kesimpulan}

Perancangan pembangkit listrik dengan termoelektrik menggunakan 6 sel TEG dengan seri TEC1270 yang disusun secara seri mampu menghasilkan tegangan keluaran DC dengan range 10-12V. Rangkaian konverter arus searah buck sudah mampu mengkonversi tegangan keluaran lebih rendah dari tegangan masukan. Dengan tegangan masukan 10-12V tegangan keluaran konverter buck sebesar $5 \mathrm{~V}$. Berdasarkan hasil pengujian tegangan keluaran buck converter dengan umpan balik tegangan pada beban $220 \Omega$ menghasilkan tegangan keluaran sebesar 5,001 volt, pada beban $100 \Omega$ menghasilkan tegangan keluaran sebesar 5,015 volt. Beban $75 \Omega$ tegangan keluaran buck converter sebesar 5,014 volt. Beban $50 \Omega$ tegangan keluaran buck converter sebesar 5,013 volt. Beban $30 \Omega$ tegangan keluaran buck converter sebesar 5,009 volt. Beban $15 \Omega$ tegangan keluaran buck converter sebesar 4,28 volt, tegangan keluaran buck converter dengan umpan balik tegangan cenderung konstan dengan tegangan $5 \mathrm{~V}$, namun pada beban $15 \Omega$ tegangan keluaran turun menjadi $4,28 \mathrm{~V}$. Hal ini karena daya yang dihasilkan TEG tidak mampu menyuplai beban $15 \Omega$. Berdasarkan hasil pengujian efisiensi buck converter dengan umpan balik tegangan yang dibuat memiliki efisiensi tertinggi yaitu $67,9 \%$ ketika beban 15
$\Omega$ dan efisiensi terendah yaitu $54 \%$ ketika beban $220 \Omega$, nilai efisiensi buck converter dengan umpan balik tegangan memiliki efisiensi dengan nilai rata-rata tiap variasi beban diatas $60 \%$. Penelitian ini dapat dikembangkan dengan menggunakan pemanas dengan suhu yang konstan, menambah sel TEG yang digunakan, dan menggunakan modul TEG dengan daya lebih besar.

\section{Referensi}

[1]. D. Champier, "Thermoelectric generators: A review of applications," Energy Convers. Manag., vol. 140, pp. 167-181, 2017.

[2]. D. KETENAGALISTRIKAN, Statistik Ketenagalistrikan 2016, 2016th ed. 2017.

[3]. D. E. dan KE, Statistik EBTKE 2016, 2016th ed. Jakarta, 2016.

[4]. M. A. B. M. SOHID and This, "DESIGN AND DEVELOPMENT OF ENERGY CONVERSION SYSTEM BY USING THERMOELECTRIC GENERATOR (TEG)," Univ. Tech. Malaysia Melaka, no. June, 2014.

[5]. S. Wango, "SMART POWER GENERATION FROM WASTE HEAT BY THERMO," Int. J. Mech. Prod. Eng., pp. 45-49, 2016.

[6]. E. Kanimba and Z. Tian, "Modeling of a Thermoelectric Generator Device Technology \& Medicine," INTECH, no. February 2017, 2016.

[7]. T. Power, "Small Thermoelectric Generators," INTERFACE, no. 2, pp. 2-4, 2008.

[8]. H. A. AL FIKRI, "EFEKTIFITAS MODUL PELTIER TEC-12706 SEBAGAI GENERATOR DENGAN MEMANFAATKAN ENERGI PANAS DARI MODUL PELTIER TEC-12706," Univ. Muhammadiyah Surakarta, 2016.

[9]. T. Jeng, S. Tzeng, B. Yang, and Y. Li, "Design , Manufacture and Performance Test of the Thermoelectric Generator System for Waste Heat," no. 1, pp. 1-16, 2016.

[10]. G. Li, "Recent development and application of thermoelectric generator and cooler," Appl. Energy, vol. 143, no. December 2014, pp. 1-25, 2017.

[11]. C. Pline, "Peltier Cooling Module Installation," no. February, 2009.

[12]. D. W. Hart, Power Electronics. Indiana: Pearson Education, Inc.

[13]. L. W. Cahyadi, KINERJA KONVERTER ARUS SEARAH TIPE BUCK CONVERTER DENGAN UMPAN BALIK TEGANGAN BERBASIS IC TL494. Semarang, 2017.

[14]. T. Instruments, "TL494 Pulse-Width-Modulation Control Circuits," 2017.

[15]. I. I. Rectifier, "HEXFET Power MOSFET," vol. PD94053, pp. 1-9, 2001.

[16]. Intersil, “MUR1560,” no. 2778, pp. 1-4, 2000. 